\title{
PERANCANGAN PENILAIAN KINERJA DENGAN METODE BEHAVIORALLY ANCHOR RATING SCALE DI PT. ZENO ALUMI INDONESIA
}

\author{
Ogie Kustiadi, Zulfa Fitri Ikatrinasari \\ Program Studi Teknik Industri - Universitas Mercu Buana, Jakarta \\ Jl. Meruya Selatan, Kebon Jeruk, Jakarta Barat \\ Email: ogiekustiadi@gmail.com
}

\begin{abstract}
Performance appraisal has an important role and function for a company it will of course be related to decision which will be taken company as company strategy in the future. This applies also to PT. Zeno Alumi Indonesia which is an aluminum injection company for spare parts of two-wheeled vehicles and four wheels. The current rating that runs on PT. Zeno Alumi Indonesia is an assessment based on the current criterion criterion criterion is not standardized so that the employee's assessment runs subjectively, so it raises the problem on the employee so that the current assessment is considered less effective and less in line with the company's objectives. As a result, employees feel uncomfortable and unmotivated at work. To overcome these problems, a performance assessment is based on the Behaviorally Anchor Rating Scale (BARS) method, the BARS method is expected to overcome the problem in the initial employee performance appraisal become more objective again in the end the employees of PT.Zeno Alumi Indonesia can work comfortably and have a high degree of innovation in working.
\end{abstract}

Keywords :Performance Appraisal, Behaviorally Anchor Rating Scale (BARS)

\begin{abstract}
ABSTRAK
Penilaian kinerja mempunyai peranan dan fungsi yang penting bagi sebuah perusahaan hal tersebut tentu saja akan berhubungan dengan keputusan yang akan diambil perusahaan sebagai strategi perusahaan dimasa yang akan datang. Hal ini berlaku juga untuk perusahaan PT. Zeno Alumi Indonesia yang merupakan perusahan injeksi alumunium untuk sparepart kendaraan roda dua maupun roda empat. Penilaian saat ini yang berjalan di PT. Zeno Alumi Indonesia adalah penilaian berdasarkan kriterian namun saat ini penilaian kriterian tersebut tidak memiliki standar yang baku sehingga penilaian karyawan berjalan secara subjektif, hal tersebut menimbulkan permasalahan pada karyawan sehingga penilaian saat ini dirasa kurang efektif dan kurang sejalan dengan tujuan perusahaan. Akibatnya karyawan merasa tidak nyaman dan tidak termotivasi dalam bekerja. Untuk mengatasi permasalahan tersebut maka disusun penilaian kinerja berdasarkan metode Behaviorally Anchor Rating Scale (BARS), metode BARS ini diharapkan dapat mengatasi masalah dalam penilaian kinerja karyawan yang semula bersifat subjektif menjadi lebih objektif lagi dimana pada akhirnya karyawan PT. Zeno Alumi Indonesia dapat berkerja dengan nyaman dan memiliki motivasi yang tinggi dalam bekerja.
\end{abstract}

Kata kunci : Penilaian Kinerja Karyawan, Behaviorally Anchor Rating Scale (BARS)

\section{PENDAHULUAN}

Saat ini persaingan perusahaan-perusahaan baik perusahaan jasa maupun industri semakin ketat didalam berkompetisi. Perusahaan-perusahaan tersebut dituntut dapat memberikan 
pelayan dan juga hasil terbaik bagi pelanggannya dan juga rekanan usahanya. Dengan alasan tersebut menjadikan faktor sumber data manusia di tuntut untuk dapat menampikan hasil yang terbaik sehingga perusahaan dapat bersaing dengan industri-industri lainnya.

Sumber daya manusia mempunyai peranan yang sangat penting bagi sebuah perusahaan sehingga diperlukan suatu sistem dimana dapat mengukur kinerja dari seorang karyawan atau performance appaisal karyawan. Setiap karyawan pastinya menginginkan memiliki karyawan yang kinerja serta perfomance nya sesuai dengan standar yang telah ditetapkan oleh perusahaan bahkan lebih baik lagi dari standar yang ada. Salah satu cara untuk mengetaui hal tersebut adalah dengan dilaksanakanya penilaian kinerja terdahap karyawan, dengan dilaksanakannya penilaian kinerja ini diharapkan perusahaan dapat mengetahui kondisi, keadaan, dan prilaku karyawan pada umumnya yang berhubungan dengan perusahaan, sekaligus dapat memberikan masukan mengenai pelatihan karyawan apa yang diperlukan kedepannya sehingga program pengembangan karyawan dapat berjalan dengan baik sesuai dengan kebutuhan karyawan serta kebutuhan perusahaan itu sendiri. Selain untuk pengembangan karyawan penilaian kinerja itu sendiri dapat dijadikan acuan untuk melakukan promosi, demosi ataupun mutasi karyawan.

Mathis dan Jackson (2006 : 382) menyatakan bahwa penilaian kinerja karyawan adalah proses mengevaluasi seberapa baik karyawan melakukan pekerjaan mereka jika dibandingkan dengan seperangkat standar dan kemudian mengkomunikasikan informasi tersebut pada karyawan. Penilaian karyawan bisa dibilang efektif apabila meliputi dua hal, yaitu :

1. Adanya seperangkat standar

2. Komunikasi informasi / Feed back

Pernyataan tersebut didukung oleh Gery Dessler. Dessler (2013 : 310) "Effective appraisal also requirs taht the supervisor set performance standards. And it requires that the employee receives the trainning, feedback, and incetives required to eliminate performance deficiencies". Pendapat tersebut semakin mempertegas bahwa penilaian kinerja karywan yang efektif membutuhkan standar yang telah ditetapkan sebelumnya serta umpan balik guna mencegah terjadinya performance yang menurun pada karyawan. Dengan melakukan penilai kinerja karyawan yang efektif perusahaan akan dapat mengoptimalkan karyawannya demi tercapainya tujuan perusahaan dapat sekaligus membuat karyawan menjadi termotivasi untuk menjadi lebih baik. Namun sebaliknya penilaian karyawan yang tidak baik akan menyebabkan banyak dampak negatif bagi karyawan dan juga perusahaan yang menaungi karyawan tersebut, dampak negatif tersebut akan muncul berupa keluhan-keluhan dari karyawan ataupun tuntutan dari karyawan serta motivasi karyawan yang rendah akan diiringi oleh tingkat keluar masuk yang tinggi.

Mengenai hal tersebut dapat terjadi pada setiap perusahaaan baik perusahaan yang berskala kecil, menengah, maupun skal besar. PT. Zeno Alumi Indonesia ada perusahaan asing yang berdiri sejak tahun 2010 dimana saat ini perusahaan ini memiliki karyawan sebanyak 115 orang, dimana untuk pimpinan tertinggi dipegang oleh orang asing. Saat ini PT. Zeno Alumi Indonesia setiap tahun selalu melakukan penilai terhadap kinerja perusahaan atau penilai kinerja dalam rangka melakukan review untuk melakukan perpanjangan kontrak karyawan ataupun untuk pengangkatan karyawan dari karyawan kontrak menjadi karyawan tetap.

Saat ini PT.Zeno Alumi Indonesai memiliki form penilaian karyawan yang terbagi menjadi 5 kategori utama yaitu :

1. Pengetahuan

2. Perilaku Kerja

3. Kepribadian

4. Kepemimpinan

5. Dan, Manajerial 
Kategori penilai tersebut di bagi dalam 3 level posisi atau jabatan dimana untuk nomor 1 sampai dengan 3 penilain dilakukan untuk tingkat operator dan se-level-nya, sedangkan untuk posisi staf, leader, supervisor penilaian dilakukan dari mulai nomor 1 sampai dengan nomor 4, sedangkan untuk level head section penilai dilakukan mulai dari nomor 1 sampai dengan nomor 5. Penilai dilakukan pada setiap jenjang jabatan dan untuk posisi leader, staf, supervisor, dan head section telah memilik targetnya masing-masing sesuai dengan jabatan yang diembannya. Namun pada pelaksanaanya beberapa karyawan menganggap penilaian kinerja tersebut merupakan formalitas semata karena penilaian akhir akan tergantung pimpinan tertinggi di perusahaan. Saat ini PT. Zeno Alumi Indonesai melakukan penilai dengan menggunakan metode skala nilai, dimana nilai-nilai tersebut diberikan oleh pimpin sesuai dengan selera dari pimpinan masing-masing departemen dimana dengan demikian standar penilai yang berikan menjadi tidak memiliki standar karena pimpinan dari masingmasing departemen akan akan melakukan penilai yang tidak akurat.

Ketidakjelasan standar dalam melakukan penilai kinerja karyawan tersebut memiliki dampat ketidaknyaman dan keadilan pada karyawan, karena karyawan merasa penilaian yang baik diperoleh apabila karyawan tersbut memiliki unsur kedekatan dengan atasan dari karyawan yang bersangkutan, sehingga hal tersebut menimbulkan perasaan takut kepada atasan apabila tidak mengikuti keingin atasan, dan hal tersebut juga menimbulkan kreatifitas karyawan menjadi tidak berkembang karena terbatasi oleh kebijakan atasanya.

Berangkat dari kondisi tersebut maka diperlukan adanya pembenahan dalam hal penilaian kinerja karyawan di PT.Zeno Alumi Indonesia, dimana penilai tersebut akan memiliki standar yang jelas dalam melakukan penilai terhadap karyawan sehingga akan di peroleh karyawan yang memiliki kinerja baik yang pada akhirnya dapat meningkatkan kinerja serta meningkatkan produktivitas karyawan yang pastinya akan memberikan dampak positif bagi perusahaan. Salah satu metode yang yang dapat digunakan dan memiliki kemiripan kondisi saat ini adalah Metode Behaviorally Anchor Rating Scale (BARS). Metode BARS adalah sebuah metode penilaian yang membidik pada kombinasi kritis dan peringkat dengan menggunakan skal yang menggambarkan secara spesifik tentang kinerja yang baik dan buruk (Dessler,2013:310). Metode ini dirasakan akan cocok dikarenakan metode ini sangat akurat dalam menilai perilaku kerja setiap karyawan (Dessler,2013:331).

\section{KAJIAN PUSTAKA}

Menurut beberapa literatur mengenai definisi penilaian kinerja sebagai berikut, pendapat Dessler (2013:310) penilai kinerja dapat didefinisikan sebagai berikut "Performance appraisal means evaluating an employee's current and / or past performance relative to his / her performance standards". Selain definis penilaian kinerja Dessler (2013:310) mengemukakan bahwa "Effective appraisal also requires that the supervisor set performance standards. And it requires that the employee receives the training, feedback, and incentives required to eliminate performance deficiencies. ". pendapat lainnya disampaikan oleh Mathis dan Jackson (2006:382) sebagai berikut "Penilaian kinerja adalah proses mengevaluasi seberapa baik karyawan melakukan pekerjaan mereka jika dibandingkan dengan seperangkat standar, dan kemudian mengkomunikasikan informasi tersebut pada karyawan”. Dari beberapa pengertian tersebut dapat disimpulkan bahwa penilaian kinerja adalah serangkaian aktivitas evaluasi yang dilakukan secara sistematis mengena performa dari seorang karyawan, dengan cara membandingkan kinerja aktual dengan standar yang telah ditetapkan oleh perusahaan dengan disertai umpan balik dalam rangka pengembangan karyawan. Terdapat beberapa alasan bagi perusahaan kenapa harus melakukan penilai kinerja, menurut Dessler (2008:293) alasan perusahaan melakukan penilai kinerja bagi karyawanya sebagai berikut :

1. Berdasarkan pandangan praktis, sebagian besar keputusan pembayaran dan promosi karyawan diambil melalui penilaian kinerja karyawan tersebut. 
Jurnal Inkofar * Volume 1 No. 1, Juli 2018 * ISSN: 2615-3645 (Print) / 2581-2920 (Online)

Tersedia secara online di: http://www.politeknikmeta.ac.id/meta/ojs/

2. Penilaian memainkan peran integral dalam performa manajemen proses perusahaan. Penilaian dapat menerjemahkan tujuan strategis perusahaan ke dalam tujuan spesifik karyawan.

3. Penilaian memberikan atasan dan bawahan mengembangkan sebuah rencana untuk mengoreksi berbagai kekurangan, dan untuk memperkuatkan hal-hal yamg telah dilakukan bawahan dengan baik dan benar.

4. Penilaian akan membantu sebuah tujuan perencanaan karir yang berguna. Penilaian menyediakan sebuah kesempatan untuk mengulas perencanaan karir (career plan) karyawan dalam cakupan kekuatan dan kelemahan tersebut.

Metode-metode Penilaian Kinerja Terdapat beberapa metode yang dapat diterapkan oleh perusahaan dalam melakukan penilaian kinerja pada karyawannya. Menurut Dessler (2008: 295), metode-metode dalam penilaian kinerja karyawan adalah sebagai berikut:

1. Metode Skala Penilaian Grafik (Graphic Rating Scale Method) adalah sebuah skala yang mencatatkan sejumlah ciri-ciri (seperti kualitas dan kepercayaan) dan jangkauan nilai kinerja (dari tidak memuaskan sampai luar biasa) untuk setiap ciri.

2. Metode Peringkat Alternasi (Alternation Ranking Method), dilakukan dengan cara membuat peringkat karyawan dari yang terbaik sampai yang terburuk pada satu atau banyak ciri.

3. Metode Perbandingan Berpasangan (Paired Comparison Method) merupakan metode yang dilakukan dengan cara memberi peringkat pada karyawan dengan membuat peta dari semua pasangan karyawan yang mungkin untuk setiap ciri dan menunjukkan mana yang lebih baik dari pasangannya.

4. Metode Distribusi Paksa (Forced Distribution Method) adalah sistem penilaian kinerja yang mengkalsifikasikan karyawan menjadi 5 hingga 10 kelompok kurva normal dari yang paling rendah sampai yang paling tinggi. Manajer atau supervisor terlebih dahulu mengobservasi kinerja karyawan, kemudian memasukannya ke dalam klasifikasi karyawan.

5. Metode Insiden Kritis (Critical Incident Method), dalam metode ini penilai membuat catatan yang berisi contoh-contoh kebaikan yang tidak umum dan tidak dilakukan dengan waktu yang pasti kemudian penilai mengulasnya dengan karyawan pada waktu yang telah ditentukan sebelumnya.

6. Behaviorally Anchor Rating Scale (BARS) adalah metode penilaian kinerja yang membidik pada kombinasi insiden kritis dan peringkat (quantified ratings) dengan menggunakan skala yang menggambarkan secara spesifik tentang kinerja yang baik dan buruk.

7. Management by Objectives (MBO), dilakukan dengan cara menetapkan tujuan spesifik setiap karyawan yang dapat diukur perkembangannya secara periodik.

8. Electronic Performance Monitoring, dilakukan melalui pengawasan secara elektronik. Dengan metode ini, dihasilkan data terkomputerisasi seorang karyawan per hari dan kinerjanya.

\section{Behaviorally Anchor Rating Scale (BARS)}

Metode BARS merupakanmetode yang menggabungkan pendekatan perilaku kerja dengan sifat pribadi karyawan. Metode ini terdiri atas satu seri, 5 hingga 10 skala perilaku vertikal untuk setiap indikator kerja. Untuk setiap dimensi disusun 5 hingga 10 anchor. Anchor tersebut yaitu perilaku yang menunjukan kinerja untuk setiap dimensi, dan nilainya disusun dari yang nilai pealing tinggi hingga nilai paling rendah.

Anchor tersebut dapat berupa critical incident yang diperoleh melalui analisa jabatan, metode ini biasanya disusun oleh tim yang terdiri dari pakar SDM, Manajer, dan pegawai dimana tim ini bertugas untuk mengidentifikasi karakteristik dimensi kinerja dan mengidentifikasi 5 
hingga 10 kejadian khusus untuk setiap dimensi yang kemudian setiap kejadian tersebut dilakukan analisa oleh tim. Kejadian yang terpilih ditempatkan dalam skala yang paling tinggi sampai dengan skala paling rendah.

Dalam pelaksanaan BARS setidaknya memerlukan lima tahap yaitu :

1. Membuat critical incident. Hal ini dilakukan dengan cara bertanya seseorang yang mengetahui pekerjaan (pemegang jabatan dan / atau penyelia) untuk menjelaskan ilustrasi khusus (kejadian kritis) kinerja yang efektif dan tidak efektif ataupun bisa dilakukan dengan cara anlisis jabatan.

2. Mengembangkan dimensi kinerja dimana dalam tahap ini kejadian tersebut dikelompokkan ke dalam kelompok yang lebih kecil dimensi kerja dan didefinisikan setiap dimensi, seperti "keterampilan menjual".

3. Mengalokasikan kembali kejadian. Kelompok lain dari orang-orang yang juga mengetahui pekerjaan ini kemudian mengalokasikan kembali kejadian kritis ini dari awal. Mereka membuat definisi pengelompokan dan kejadian kritis, dan harus menugaskan kembali setiap kejadian untuk kelompok yang mereka anggap paling sesuai.

4. Membuat skala kejadian. Membuat peringkat perilaku yang dijelaskan oleh kejadian itu dengan seberapa efektif dan efisien. Setiap perilaku merepresentasikan kinerja pada dimensinya.

5. Mengembangkan perangkat akhir. Pilih 5 hingga 10 kejadian sebagai standar perilaku dimensi itu.

Pelaksanaan dengan metode BARS memiliki kelemahan yaitu menyita waktu jika dibandingkan dengan metode penilain lainnya, namun selain kelemahan BARS juga memilki kelebihan yaitu :

1. Ukuran yang lebih akurat. Orang yang mengembangkan metode BARS adalah mereka yang ahli dibidang SDM selain itu diikut sertakan juga orang yang tahu pekerjaan dengan baik.

2. Standar yang lebih jelas. Kejadian kritis di sepanjang skala menjelaskan apa yang harus dicari berkaitan dengan kinerja superior, kinerja rata-rata dan seterusnya.

3. Umpan balik. Kejadian kritis memudahkan untuk menjelaskan peringkat pada yang dinilai.

4. Dimensi independen. Pengelompokan secara sistematis kejadian kritis ke dalam 5 hingga 10 dimensi kerja (seperti "keterampilan menjalankan mesin").

5. Konsistensi. Penilaian kinerja berdasarkan metode BARS tampaknya juga konsisten dan dapat dipercaya secara relatif, karena penilaian yang diberikan oleh penilai yang berbeda-beda terhadap orang yang sama akan cenderung sama.

\section{METODE PENELITIAN}

Penelitian mempunyai sifat deskriptif karena berusha mendeskripsikan suatu gejala, peristiwa, dan kejadian yang terjadi saat ini, dimana metode ini berusaha mengambarkan masalah mengenai penilaian kinerja karyawan di PT. Zeno Alumi Indonesia dimana penilaian kinerja yang dilakukan saat ini dirasa kurang efektif dalam pelaksanaannya. Pada penelitian ini teknik yang digunakan untuk pengumpulan data yaitu :

1. Field Research

Pengumpulan data yang dilakukan dengan cara mengamati pekerjaan dan juga prosedure yang dilaksanakan di perusahaan. Selain Field Research teknik yang dilakukan adalah melakukan wawancara dengan cara tanya jawab langsung kepada pihak-pihak terkait baik manajemen ataupun karyawan. 


\section{Studi Pustaka}

Dengan mempelajari buku-buku literatur, jurnal dan karya tulis ilmiah terdahulu yang membahas mengenai penilaian kinerja karyawan. Dan juga untuk melengkapi penulisan ini ditambah informasi pendukung lainya, seperti : Peraturan perusahaan, struktur organisasi, Visi misi, Job description karyawan dan tentu saja penilain karyawan yang saat ini berjalan.

\section{HASIL PENELITIAN DAN PEMBAHASAN}

Sehubungan dengan belum sempurnanya penilaian kinerja yang selama ini di jalankan di PT. Zeno Alumi Indonesia, hal tersebut membuat PT. Zeno Alumi Indonesia mengharapakan pembenahan terhadap metode penilaian kinerja karyawanya. Berdasarkan data sebelumnya maka pembenahan penilaian kinerja karyawan akan menggunakan metode Behaviorally Anchor Rating Scale (BARS) untuk menilai perilaku dan kinerja karyawan.

Form penilai kinerja yang saat ini digunakan di PT. Zeno Alumi Indonesian memiliki 5 kategori utama yaitu :

1. Pengetahuan umum

2. Perilaku kerja

3. Kepribadian

4. Kepemimpinan

5. Manajerial

\begin{tabular}{|c|c|c|c|c|c|c|c|c|}
\hline \multicolumn{9}{|c|}{ A. DENTITASKARYAWAN } \\
\hline \multirow{4}{*}{\multicolumn{2}{|c|}{$\begin{array}{l}\text { Nama Karyawan / Employee Name } \\
\text { Jabatan / Position } \\
\text { Departemen / Dept } \\
\text { Atasan / Leader }\end{array}$}} & & & & & \\
\hline & & & & & & & & \\
\hline & & 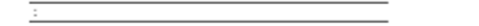 & \multirow{2}{*}{\multicolumn{3}{|c|}{ TMrr / Jobnt Dase }} & & & \\
\hline & & & & & & & & \\
\hline \multicolumn{9}{|c|}{ B. WORK PERFORMANCE } \\
\hline \multirow[b]{2}{*}{ No } & \multirow{2}{*}{ Kriteria/ Criteria } & \multirow[b]{2}{*}{ Desikripsi / Description } & \multicolumn{5}{|c|}{ Nilai / Score } & \multirow{2}{*}{$\begin{array}{l}\text { Rata-rata/ } \\
\text { Average }\end{array}$} \\
\hline & & & 0 & 25 & so & 75 & 100 & \\
\hline \multirow{3}{*}{1} & \multirow{3}{*}{$\begin{array}{l}\text { Pengetahuan/ } \\
\text { Roowiedge }\end{array}$} & $\begin{array}{l}\text { Pengetahuan Umum / } \\
\text { General Konowledge }\end{array}$ & & & & & & Average $=n / 3$ \\
\hline & & $\begin{array}{l}\text { Kemampuan analisa masalah/ } \\
\text { Abitity to anajues problems }\end{array}$ & & & & & & \\
\hline & & $\begin{array}{l}\text { Keahlian dibidangrya/ } \\
\text { Expertise in their feeld }\end{array}$ & & & & & & \\
\hline \multirow{6}{*}{2} & \multirow{6}{*}{$\begin{array}{l}\text { Prilaku kerja/ } \\
\text { Work behanior }\end{array}$} & $\begin{array}{l}\text { Displin Tepat Wainu, Rajin, Cekatan / } \\
\text { Timmesy diectiplise, diligence, Retort }\end{array}$ & & & & & & Average $=n 6$ \\
\hline & & $\begin{array}{l}\text { Bekerjasama dengan tim/ } \\
\text { In colliaboration with the team }\end{array}$ & & & & & & \\
\hline & & 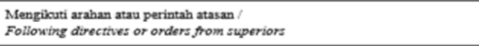 & & & & & & \\
\hline & & $\begin{array}{l}\text { Inisiatifkerja/ } \\
\text { Employment intiative }\end{array}$ & & & & & & \\
\hline & & 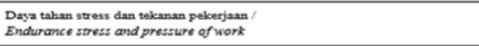 & & & & & & \\
\hline & & 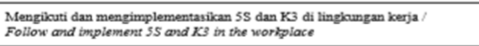 & & & & & & \\
\hline \multirow{4}{*}{3} & \multirow{4}{*}{$\begin{array}{l}\text { Kepribadian / } \\
\text { Perronality }\end{array}$} & $\begin{array}{l}\text { Rasa percaya diri dalam bekerja / } \\
\text { Confidence in the work }\end{array}$ & & & & & & Average $=n / 4$ \\
\hline & & $\begin{array}{l}\text { Kemampuan berkomunikasis dengan rekan kerja, bawahan dan atasan / } \\
\text { The ab bility to commevicate with co-korkers, subordinates and superiors }\end{array}$ & & & & & & \\
\hline & & $\begin{array}{l}\text { Pengendalian emosi// } \\
\text { Emotional control }\end{array}$ & & & & & & \\
\hline & & $\begin{array}{l}\text { Tangzung jawab dan setia terhadap persuahaan / } \\
\text { Retponsiblitipy and loyal to the compowy }\end{array}$ & & & & & & \\
\hline \multirow{4}{*}{4} & \multirow{4}{*}{$\begin{array}{l}\text { Kepemimpinan/ } \\
\text { Leaderzhip }\end{array}$} & $\begin{array}{l}\text { Kemampuan memimpin dan penganuran waitu yang baik / } \\
\text { Ability to lead ard setting a good time }\end{array}$ & & & & & & Average $=14$ \\
\hline & & 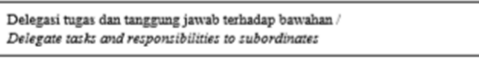 & & & & & & \\
\hline & & 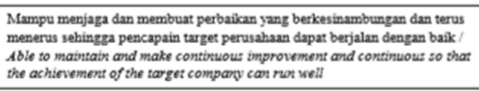 & & & & & & \\
\hline & & $\begin{array}{l}\text { Kemampuan menganalisa dan dan menzambil keputuan yang dipertukan / } \\
\text { And the ablity to arajze eand mate decitions necessary }\end{array}$ & & & & & & \\
\hline \multirow{3}{*}{5} & \multirow{3}{*}{$\begin{array}{l}\text { Manajerial/ } \\
\text { Maragerial }\end{array}$} & $\begin{array}{l}\text { Kemampuan dalam membuat Perencanaan, Pelakianaan, Pengatuasan dan } \\
\text { Pengoutrolan / } \\
\text { The ability to crease Plavning. Implementation, Monitoring and Conzol }\end{array}$ & & & & & & Average $=\mathrm{n} 3$ \\
\hline & & 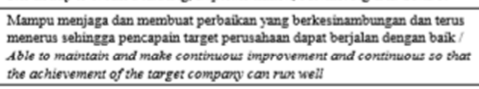 & & & & & & \\
\hline & & 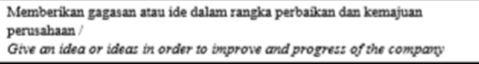 & & & & & & \\
\hline
\end{tabular}

Gambar 1. Form Penilaian Karyawan 
Jurnal Inkofar * Volume 1 No. 1, Juli 2018 * ISSN: 2615-3645 (Print) / 2581-2920 (Online)

Tersedia secara online di: http://www.politeknikmeta.ac.id/meta/ojs/

Dimana pada form penilaian karyawan tersebut range penilai tidak terlihat sehingga bobot untuk penilaian karyawan tidak menjadi tidak jelas dan untuk indikator pembobotannya tidak ada.

Dengan metode BARS kita akan melakukan perumusan rating untuk setiap kriteria penilaian karyawan. Untuk perumusan dengan metode BARS ini dapat dilihat pada tabel dibawah ini.

\begin{tabular}{|c|c|c|}
\hline Indikator & Rating & Anchor \\
\hline \multirow{5}{*}{ Disiplin } & 5 & Hadir tepat waktu secara konsisten dengan keterlambatan $0 \%$ \\
\hline & 4 & Tingkat kehadiran $\geq 95 \%$ \\
\hline & 3 & Hadir tetapi kdang suka terlambat datang dengan kondisi mendapatkan ijin \\
\hline & 2 & Tingkat absnesi $>10 \%$ dan datang terlambat \\
\hline & 1 & Sering datang terlambat dan record absen yang tidak jelas \\
\hline \multirow{5}{*}{$\begin{array}{c}\text { Tanggung } \\
\text { Jawab }\end{array}$} & 5 & $\begin{array}{l}\text { Selalu mengerjakan tugas yang diberikan, dan menyelesaikan tugas tepat waktu serta hasil sesuai dengan instruksi } \\
\text { pimpinan }\end{array}$ \\
\hline & 4 & Selalu mengerjakan tugas yang diberikan dan menyelesaikan tugas tepat waktu meski kadang-kadang melakukan kesalahan \\
\hline & 3 & Mengerjakan tugas yang diberikan meskipun terlambat dan kurang tepat dengan apa yag diinstruksikan \\
\hline & 2 & Mengerjakan tugas namun sering terlambat menyelesaikan dan banyak ditemui kesalahan \\
\hline & 1 & Sering tidak mengerjakan tugas yang diinstrusksikan \\
\hline \multirow{5}{*}{ Teamwork } & 5 & $\begin{array}{l}\text { Mampu berkomunikasi dan berkoordinasi dengan berbagai pihak, serta menghargai pendapat dan masukan orang lain } \\
\text { secara konsisten }\end{array}$ \\
\hline & 4 & Mengetahu tugas orang lain yang berhubungan dengan tugasnya serta bersedia mempertimbangkan usulan dari orang lain \\
\hline & 3 & $\begin{array}{l}\text { Mengetahu garis besar tugas orang lain yang berhubungan dengan tugasnya dan sesekali harus diyakinkan terlebih dahulu } \\
\text { untuk menyesuaikan pendapatanya. }\end{array}$ \\
\hline & 2 & $\begin{array}{l}\text { Enggan menerima keputusan bersama apabila bertentangan dengan pendapatnya serta tidak mengetahui secara pasti tugas } \\
\text { orang lain yang berhubungan dengannya }\end{array}$ \\
\hline & 1 & $\begin{array}{l}\text { Sama sekali tidak mampu berkoordinasi dan berkomunikasi dengan berbagai pihak dan tak mampu menghargai pendapat } \\
\text { orang lain }\end{array}$ \\
\hline \multirow{5}{*}{ Leadership } & 5 & Bertindak tegas dan tidak memihak serta menjadi teladan \\
\hline & 4 & Bertindak tegas dan tidak memihak serta mampu mengemukakan pendapat dengan jelas \\
\hline & 3 & Bersikap sedikit memihak namun masih dalam batasan yang wajar \\
\hline & 2 & Kadang mudah dipengaruhi \\
\hline & 1 & Tidak mampu bertindak tegas dan memihak \\
\hline \multirow{5}{*}{$\begin{array}{c}\text { Problem } \\
\text { solving } \\
\text { and } \\
\text { Decision } \\
\text { Taking } \\
\text { Skills } \\
\end{array}$} & 5 & Mampu merumuskan alternatif solusi yang relevan dan applicable guna menyelesaikan masalah \\
\hline & 4 & Menciptakan solusi temporer atas masalah yang terjadi \\
\hline & 3 & Mampu membuat keputusan tanpa pertimbangan reaksi dari bawahan \\
\hline & 2 & Mementingkan kepentingan pribadi pada saat membuat keputusan \\
\hline & 1 & Menolak membuat keputusan saat dibutuhkan \\
\hline \multirow{5}{*}{ Kepatuhan } & 5 & Selalu mentaati peraturan peraturan dan prosedure kerja serta menepati instruksi yang diberikan atasan \\
\hline & 4 & $\begin{array}{l}\text { Sesekali tidak mentaati aturan-aturan dan prosedur kerja serta menepati instruksi yang diberikan atasan namun masih dalam } \\
\text { batasan yang wajar }\end{array}$ \\
\hline & 3 & $\begin{array}{l}\text { Tidak mentaati aturan-aturan dn prosedur kerja serta menepati instruksi yang diberikan atasn namun masih dalam batasan } \\
\text { yang wajar }\end{array}$ \\
\hline & 2 & Kadang-kadang melakukan pelanggaran atas aturan-aturan dan prosedure kerja serta instruksi dari atasan \\
\hline & 1 & Sering melanggar aturan-aturan dan prosedure kerja juga instruksi yang berikan atasan \\
\hline \multirow{5}{*}{ Kejujuran } & 5 & Selalu melaporkan hasil kerjanya kepada atasannya menurut keadaan sebenarnya \\
\hline & 4 & Sesekali tidak melaporkan hasil kerjanya kepada atasan berdasarkan keadaan yang sebenarnya \\
\hline & 3 & $\begin{array}{l}\text { Hasil kerja yang dilaporkan pada atasanya tidak sesuai dengan keadaan yang sebenarnya namun masih pada batasn } \\
\text { toleransi }\end{array}$ \\
\hline & 2 & terkadang hasil kerja yang dilaporkan pada atasanya lebih baik dari keadaan yang sebenarnya \\
\hline & 1 & Sering melaporkan hasil kerjanya tidak sesuia dengan dengan keadaan sebenarnya \\
\hline \multirow{5}{*}{$\begin{array}{c}\text { Self- } \\
\text { Motivation }\end{array}$} & 5 & Mengerjakan tugas dengan effort yang luar biasa dengan meneriman segala konsekuensi \\
\hline & 4 & Mengerjakan tugas lebih dari yang diharapkan \\
\hline & 3 & Mengerjakan tugas sesuai dengan yang diharapkan \\
\hline & 2 & membutuhkan dorongan tambahan agar melaksanakan tugasnya \\
\hline & 1 & Mengabaikan tugas yang diberikan \\
\hline \multirow{5}{*}{$\begin{array}{c}\text { Analitical } \\
\text { Thinking }\end{array}$} & 5 & Membuat analis is atau rencana yang kompleks \\
\hline & 4 & Melihat hubungan yang komplek antar masalah \\
\hline & 3 & Mampu melihat hubungan dasar antar masalah \\
\hline & 2 & Mampu menggunakan masalah \\
\hline & 1 & Tidak mampu menguraikan masalah sama sekali \\
\hline \multirow{5}{*}{$\mid \begin{array}{c}\text { Achievmen } \\
t \\
\text { Orientation }\end{array}$} & 5 & Menyusun tujuan yang matang \\
\hline & 4 & Meningkatkan performan kerja \\
\hline & 3 & Memenuhi standar yang ditetapkan manajemen \\
\hline & 2 & Ingin bekerja dengan baik \\
\hline & 1 & Hanya focus bekerja tanpa memikirkan target yang dicapai \\
\hline \multirow{5}{*}{ Inovatif } & 5 & Melakukan hal baru ditingkat irganisasi yang menyebabkan perusahaan memiliki kinerja yang lebih baik lagi \\
\hline & 4 & melakukan hal baru ditingkat departemen sehingga meningkatkan performa departemen \\
\hline & 3 & melakukan hal baru ditingkat divisi sehingga meningkatkan performa divisi \\
\hline & 2 & Melakukan hal baru untuk meningkatkan performan kerja \\
\hline & 1 & Tidak melakukan hal baru \\
\hline
\end{tabular}

Gambar 2. Tabel Perumusan Penilaian Dengan Metode Behaviorally Anchor Rating Scale 


\subsection{Analisa Tujuan Perusahaan}

Setiap perusahaan memiliki tujuan yang ingin dicapai, dan biasanya tujuan tersebut dibagi menjadi beberap tahap seperti tujuan jangka pendek, jangka menengah, dan tujuan jangka panjang. Hal tersebut juga berlaku pada PT. Zeno Alumi Indonesia bahwa perusahaan memiliki tujuan sebagai berikut :

1. Meningkatkan produktivitas perusahaan.

2. Menurukan biaya operasional.

3. Mengurangi tingkan kerusakan ataupun cacat produk/Meningkatkan kualitas.

4. Meningkatkan keuntungan perusahaan.

\subsection{Analisis Tujuan Departemen}

Analisis tujuan departemen merujuk pada tujuan perusahaan, tujuan perusahaan tersebut harus dapat diturunkan pada masing-masing departemen sehingga masing-masing departemen dapat menyusun rencana kerja guna mencapai tujuan perusahaan yang telah di tetapkan.

Tujuan masing-masing derpatemen dapat dilihat sebagai berikut :

1. Human Resource Development (HRD)

- Memenuhi kebutuhan karyawan sesuai dengan permintaan dari masing-masing departemen dan sesuai dengan rencana kebutuhan karyawan.

- Meningkatkan keterampilan karyawan dengan pelaksanaan pelatihan.

- Meningkatkan disiplin karyawan.

2. Akunting dan Keuangan

- Ketepatan dalam memeriksa tagihan dari supplier.

- Membuat transaksi harian dengan tepat.

- Membuat tagihan dengan akurat dan tepat waktu.

3. Sales

- Menjaga kepuasan pelanggan.

- Miningkatkan nilai penjualan produk.

4. Produksi

- Membuat produk sesuai dengan rencana produksi yang telah ditetapkan.

- Reject material kurang dari 5\%

5. Enginering dan Maintenance

- Memastikan peralatan dan mesin dapat bekerja secara optimal.

- Mengurangi waktu downtime mesin.

6. Quality Control

- Mengurangi dan mengontrol defect produk yang diakibatkan dari proses produksi yang tidak sesuai dengan instruksi kerja.

\subsection{Perumusan Bobot dan Target}

Perumusan bobot dan target setiap karyawan dilakukan dengan cara menjabarkan dari tujuan perusahaan serta tujuan dari masing-masing departemen. Selain itu dilakukan juga analisis terhadap job deskripsi untuk masing-masing departemen dan sub departemen untuk menentukan indikator yang harus dicapai oleh setiap karyawan. Bobot dan terget karyawan harus dirumuskan bersama dengan kepala departemen masing-masing yang dianggap mengetahui kondisi perusahaan. Target yang disusun harus dapat dicapai dalam waktu yang telah di tetapkan bersama antara karyawan atau departemen dengan manajemen perusahaan. 
Perumusan bobot dan target ditetapkan sebagai berikut :

1. Human Resource Development

\begin{tabular}{clcc} 
No & \multicolumn{1}{c}{ Indikator } & Bobot & Target \\
1 & Jumlah pelamar dalam setiap perekrutan & 15 & 4 orang \\
2 & Waktu dalam proses rekrutmen $\leq 45$ hari & 30 & $100 \%$ \\
3 & Jumlah pelatihan yang dapat dilaksanakan & 20 & $100 \%$ \\
4 & Banyaknya surat peringatan yang dikeluarkan & 15 & 0 \\
5 & Ketepatan dalam administasi gaji karyawan & 20 & $100 \%$
\end{tabular}

2. Akunting dan Keuangan

\begin{tabular}{clcc} 
No & \multicolumn{1}{c}{ Indikator } & Bobot & Target \\
1 & Membuat tagihan kepada pelanggan tepat waktu & 40 & $100 \%$ \\
2 & Melakukan rencana pembayaran tepat waktu & 30 & $100 \%$ \\
3 & Membuat transaksi harian dengan akurat & 30 & $100 \%$
\end{tabular}

3. Sales

\begin{tabular}{clcc} 
No & \multicolumn{1}{c}{ Indikator } & Bobot & Target \\
1 & Berapa banyak pelanggan yang komplain $\leq 6$ bulan & 25 & 0 \\
2 & Kenaikan total sales per tahun & 30 & $\mathrm{Up} \mathrm{20 \%}$ \\
3 & Jumlah pelanggan baru dalam setahun & 20 & 1 \\
4 & Jumlah proyek baru per 6 bulan & 25 & 3
\end{tabular}

4. Produksi

Total $\mathbf{1 0 0}$

\begin{tabular}{clcc} 
No & \multicolumn{1}{c}{ Indikator } & Bobot & Target \\
1 & Target produksi $100 \%$ & 40 & $100 \%$ \\
2 & Reject material $<5 \%$ & 30 & $100 \%$ \\
3 & Persentasi jumlah mesin yang beroperasi & 30 & $>85 \%$
\end{tabular}

5. Enginering dan Maintenance

\begin{tabular}{clcc} 
No & \multicolumn{1}{c}{ Indikator } & Bobot & Target \\
1 & Berapa \% downtime mesin dalam 1 bulan & 30 & $>85 \%$ \\
2 & Berapa lama downtime mesin & 30 & Mak.2 hari \\
3 & Berapa banyak preventif mesin dilakukan setiap mesin & 20 & $1 \mathrm{x} / \mathrm{mesin}$ \\
4 & Berapa banyak improvement proses dilakukan & 20 & $1 / \mathrm{bln}$ \\
\multicolumn{2}{c}{ Total } & $\mathbf{1 0 0}$ &
\end{tabular}

6. Quality Control

\begin{tabular}{clcc} 
No & \multicolumn{1}{c}{ Indikator } & Bobot & Target \\
1 & Target klaim pelanggan perbulan & 25 & mak.6x \\
2 & Persentas NG di internal & 25 & $3 \%$ \\
3 & Persentas NG di External & 25 & $5 \%$ \\
4 & Kalibrasi alat ukur & 25 & $100 \%$ \\
& & Total & $\mathbf{1 0 0}$
\end{tabular}

Gambar 3. Tabel Perumusan Bobot dan Target Departemen 
Jurnal Inkofar * Volume 1 No. 1, Juli 2018 * ISSN: 2615-3645 (Print) / 2581-2920 (Online)

Tersedia secara online di: http://www.politeknikmeta.ac.id/meta/ojs/

Dari tabel BARS diatas dan juga pembobotan target pada masing-masing departemen dapat dibuat usulan baru untuk form penilaian karyawan sebagai berikut :

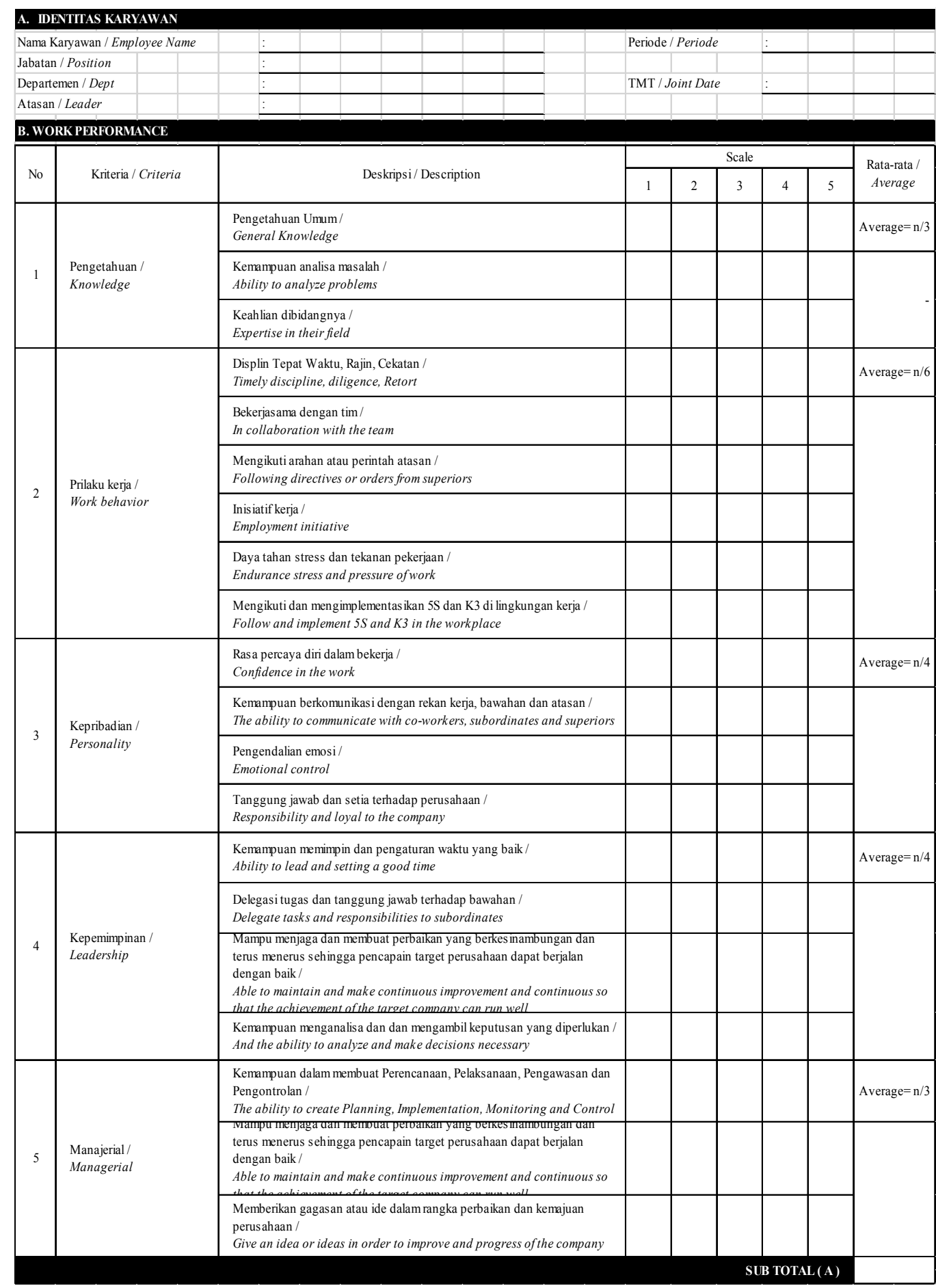

Gambar 4. Form penilaian karyawan baru berdasarkan metode BARS

Untuk form penilaian karyawan yang baru ini atasan akan menilai karyawan berasarkan skala yang ada sesuai dengan standar yang telah di tetapkan sebelumnya. Sehingga penilaian ini dapat dilaksanakan lebih objektif untuk setiap karyawan. 


\section{KESIMPULAN DAN SARAN}

Penilaian kienrja yang dilakasanakan di PT. Zeno Alumi Indonesia saat ini dilakukan tanpa adanya standar penilaian yang jelas sehingga penilaian lebih cenderung subjectif dari para atasannya, Penilaian kinerja yang efektif tentu saja harus bersifat objektif kemudian harus memiliki standar yang jelas dan terukur selain itu harus terdapat feedback atas capaian karyawan.

Untuk mengatasi permasalahan yang terjadi pada penilain kinerja yang sebelumnya, maka diusulkan pembuatan standar penilaian kienrja karyawan dengan menggunakan metode Behaviorally Anchor Rating Scale. Metode Behaviorally Anchor Rating Scale ini diharapakan menjadi sebuah jawaban atas permasalahan yang saat ini terjadi di perusahaan PT. Zeno Alumi Indonesia dimana penilaian karyawan dapat dilaksanakan secara objektif.

\section{DAFTAR PUSTAKA}

Azwar, Saifuddin. 1998. Metode Penelitian. Yogyakarta: Pustaka Pelajar.

Dessler, Gary. 2013. Human Resource Management, 13th Edition. London: Pearson Prentice Hall Inc.

Grensing, Lin. 2007. Manajemen Sumber Daya Manusia untuk Usaha Kecil dan Menengah, Alih Bahasa. Jakarta: PT Ina Publikatama.

Hasibuan, Malayu S.P. 2011. Manajemen Sumber Daya Manusia, Edisi Revisi. Jakarta: Bumi Aksara.

Mathis, Robert L. dan John H. Jackson. 2006. Manajemen Sumber Daya Manusia, Alih Bahasa. Jakarta: Salemba Empat.

Moeheriono. 2009. Pengukuran Kinerja Berbasis Kompetensi. Surabaya: Ghalia Indonesia

Robbins, Stephen P. 2008. Perilaku Organisasi Edisi Kedua belas, Jilid 1, Alih Bahasa. Jakarta: PT Indeks.

Wirawan. 2009. Evaluasi Kinerja Sumber Daya Manusi: Teori, Aplikasi, dan Penelitian. Jakarta: Salemba Empat. 